\section{Optimum limestone powder amount in mortars with over silica fume}

PAKI TURGUT - Inonu University, Civil Engineering Dept., Turkey - paki.turgut@inonu.edu.tr ABdullah OGRETMEN - Atlasyol Dam Construction Co., Turkey - abdullahogretmen63@gmail.com Érkezett: 2019. 01. 12. " Received: 12. 01. 2019. " https://doi.org/10.14382/epitoanyag-jsbcm.2019.11

\section{Abstract}

The calcium hydroxide $(\mathrm{CH})$ and the calcium silicate hydrate $(\mathrm{CSH})$ are the main hydration products of Portland cement (PC) paste. The $\mathrm{CH}$ product causes the durability problems in the PC paste due to the leaching $\mathrm{Ca}^{2+}$ ions. Silica fume is an effective pozzolan to consume $\mathrm{CH}$ in the PC paste. It is only effective to convert all $\mathrm{CH}$ to $\mathrm{CSH}$ if used in excessive amounts in the PC paste. Some problems arise related to segregation, mechanical or physical properties when it is used in excessive amounts. In this study, the optimum limestone powder amount was determined to improve these problems in the mixtures.

Keywords: self-consolidating mortar, limestone powder, silica fume Kulcsszavak: öntömörödő habarcs, mészkôliszt, szilikapor

\section{Introduction}

Self-compaction concrete (SCC) was firstly used in Japan 1990 and it has been effectively used in construction industry since this date [1]. SCC has the same main ingredients similar to the conventional concrete although the amount of powder in SCC is high compared to conventional concrete [2]. SCC is described as an easily flowable concrete having no segregation of its ingredients. In the fresh state, SCC is easily spreaded and fills moulds without compacting [3-4]. Many researches have been performed on hydration of mineral admixtures, mixture design and workability in SCC since it was invented [5]. The fresh SCC effectively covers the reinforcing bars as well as perfectly filling the moulds. The homogeneity of SCC is better than conventional concrete. Filling moulds, covering reinforcement bars and providing homogeneity of SCC is only possible by improving the rheological properties of the fresh SCC. The fresh SCC mixture should have enough plastic viscosity as well as low viscosity. The improved flowability and packing behaviour of fresh SCC can be obtained by adjusting amounts of the superplasticer and the powder amount [6]. The paste amount in SCC is also higher as compared with conventional concrete. Therefore, SCC is a landfill area for some powders having health and environmental hazards [3]. The maximum size of powder used in SCC is less than $0.125 \mathrm{~mm}$. The used amount in it varies between 380 and $600 \mathrm{~kg} / \mathrm{m}^{3}$ [2]. The viscosity of SCC mixture increases when the interaction between powder particles increases because of the increase of powder amount. The powders make the solid section richer in SCC and the coarse aggregates are well covered by mortar [7]. The use of only Portland cement (PC) as powder in SCC is uneconomical approach. Another problem is that the use of high amount PC brings the durability problem in the concrete. That is why, the determined amounts of fly ash (FA), silica fume (SF), granulated blast furnace slag (GBFS), limestone powders (LP) etc. replaced with $\mathrm{PC}$ are used in the SCC as powder. Some quarry powders used in SCC has also been popular nowadays [8]. Some properties of fresh and hardened self-compacted mortars (SCMOs) were investigated. The effects of SF or LP on mortars or concretes were detailed given in literature review as below. Ye et. al. [4] showed that LP did not contribute in the chemical reaction in the cement paste system. This was confirmed by using thermal and BSE image analysis. They also pointed out that LP acted as an accelerator during early cement hydration. The high performance concretes having high durability properties were produced by using SF [9]. SF having effective pozzolanic properties produced discontinuous and impermeable pore structures in the cement paste system as compared with those without SF [10]. Cheng and Feldman [11] urged that SF accelerated the hydration of PC in the early hours because of released $\mathrm{OH}^{-}$and alkali ions to the pore water in the paste. In the first hours, there was an increase in $\mathrm{C}_{3} \mathrm{~S}$ and $\mathrm{C}_{3} \mathrm{~A}$ hydrations. Feldman and Cheng [12] reported that the compressive strength of cement paste was decreased in the low water/binder ratios (water/binder: 0.25 ) when SF content increased. In high water/binder ratios (water/binder: 0.45), SF effectively increased the compressive strength at 1 and 180 days of age. The reason of the high compressive strength obtained in concrete with SF was the decreases in pore diameter, $\mathrm{CH}$ amount and the improved interface between paste and aggregate [12-14]. Rao [15] also investigated the effect of SF in the paste and mortar. The setting time, air content and workability were decreased when SF increased in these mixtures. The early drying shrinkage of mortars increased with the increase of SF amount while there was no any change in the late drying shrinkage. Similar results related to the drying shrinkage were found by other researchers [16-17]. Vikan and Justnes [18] performed some tests on the PC paste or mortar containing SF or LP. The viscosity of PC paste increased with the increase of SF amount, but decreased with the increase of superplasticizer amount. LP also decreased the viscosity of PC paste. It was argued that the LP distributed the PC particles more effectively than the SF. The LP had not any chemical reaction with the PC and it behaved as an inert material. In their work, the $9 \%$ LP addition effectively improved some properties of paste. Diamantonis et al. [19] made some rheological tests on the PC pastes with the natural pozzolan, SF, LP and FA or with their 
combinations. The addition of fine materials to the PC paste had a great effect on its viscosity. PC replacement with $40 \%$ LP improved the viscosity. Thus, it was proved to be the best powder. On the other hand, the SF and natural pozzolan did not show the desired effect wanted in the decrease of viscosity. LP was the preeminent powder among the powders tested. The LP greatly improved the particle packing and the deformability of the cementitious paste and reduced the amount of mixing water in the SCC [20]. The PC replacement with 10\% LP improved the compressive strength of pastes and reduced the amount of superplasticizer [21]. The LP had an improved effect on the packing, workability and stability of concrete mixtures and hardened properties of concrete by making the seeding points in the PC paste for the $\mathrm{CH}$ and $\mathrm{CSH}$ in the early hydration stage [22-26]. The LP improved the interface between PC paste and aggregate, and increased the density of PC paste [27-28]. The LP improved the shrinkage and creep deformations by influencing the interior moisture of concrete [29]. The LP having appropriate grain sizes generally improved the compressive strength of concrete [30]. It was found that the LP additive contribution to the early compressive strength was higher than both the FA and SF. The PC replacement with the 30\% LP decreased the mechanical strengths in the mortars. It was argued that the PC replacement with the 5\% or $10 \% \mathrm{LP}$ was convenient in the mortars [31]. It was also suggested that the use of SF, FA and LP combinations in the mortars was more effective than the use of them separately [31]. The LP contributed to the improvement of cement grains distribution and enhanced the stability of the mixture when used in concrete or mortar [32-33]. It was noted that the LP was very effective on the concrete rheology and provided the better cohesion and plasticity in the concrete [32]. Neto and Campitelli [34] used a two-point test technique to characterize the rheology of PC paste with the LP. They observed a decrease in the yield stress of cement paste when LP amount increased. It was reported that the PC replacements with 5 to $28 \%$ LP effectively reduced the water bleeding and did not adverse effect on the air entraining [35]. The ultra-fine LP reduced the superplasticizer amount and enriched the workability of high performance concrete [36]. Kounakoff et al. [37] reported that the addition of LS or SF to the concrete increased slightly the slump-flow values in concrete. They urged that the flowability and the segregation resistance of concrete could be improved by replacing a certain volume of PC with an identical volume of LP or SF.

The durability of Self-Consolidated Mortars (SCMOs) was increased when the SF or F-class FA converted the $\mathrm{CH}$ to $\mathrm{CSH}$ in PC paste. Therefore, the high amount of SF was needed in SCMOs to consume the $\mathrm{CH}$ effectively. When the $\mathrm{SF}$ in SCMOs was high amount in mixtures, the segregation problem occurred in fresh mixture. It was reported in earlier studies that the segregation problem occurred in the SCC or SCMOs when PC replacement with the SF was higher than $15 \%$ by weight. Therefore, the aim of this study was to find the optimum LP amount when PC replacement with SF was 25\%, and to investigate its effect on some properties of SCMOs.

\section{Materials and methods}

\subsection{Properties of materials used}

The type of PC used in this work was CEM I 42.5R. The SF and LP were used as powders. The LP was used in mixtures after sieved from $150 \mu \mathrm{m}$ mesh. The chemical compositions of materials are given in Table 1. The densities of PC, LP and SF were $3.10,2.54$ and $2.25 \mathrm{~g} / \mathrm{cm}^{3}$ while their specific surface areas were 2047, $2186\left(\mathrm{~cm}^{2} / \mathrm{g}\right)$ and 20000 (BET), respectively. The density, $\mathrm{pH}$ value and solid ratio of High range water reducer (HRWR) used were 1.06, 7.03 and 35.52\%. The river sand had the maximum grain size of $2.36 \mathrm{~mm}$ and the water saturated surface dry density of $2.65 \mathrm{~g} / \mathrm{cm}^{3}$ was used. The percentages of sand by weight satisfying ASTM C33 [38] were 10, 20, 30 and $40 \%$ for $0.15-0.30,0.30-0.60,0.60-1.18$ and $1.18-2.36 \mathrm{~mm}$, respectively.

\begin{tabular}{lcccccccccc}
$\begin{array}{l}\text { Weight } \\
\%\end{array}$ & $\mathbf{C a O}$ & $\mathbf{S i O}_{2}$ & $\mathrm{Al}_{2} \mathbf{O}_{3}$ & $\mathrm{Fe}_{2} \mathrm{O}_{3}$ & $\mathrm{Na}_{2} \mathbf{O}$ & $\mathrm{K}_{2} \mathbf{O}$ & $\mathrm{MgO}$ & $\mathbf{S O}_{3}$ & $\mathrm{Cl}$ & LOI \\
\hline PC & 63.59 & 18.90 & 5.15 & 3.36 & 0.31 & 0.77 & 1.57 & 2.65 & 0.02 & 3.59 \\
\hline LP & 51.79 & 2.19 & 0.13 & 0.07 & 0.82 & 0.02 & 1.34 & 0.04 & 0.01 & 43.60 \\
\hline SF & 1.30 & 83.14 & 0.19 & 0.24 & 0.64 & 2.62 & 4.24 & 1.04 & 0.18 & 4.77
\end{tabular}

Table 1. The chemical compositions of materials 1. táblázat A vizsgált anyagok kémiai összetétele

\subsection{Sample preparation and tests}

Five series of SCMs mixtures named as the Control, SF25, SF25LP5, SF25LP10 and SF25LP20 were prepared as given in Table 2. While the PC replacement with the SF was $25 \%$ by weight in the SF25 mixture, the Control mixture contained only PC as binder. The SF amount was constant in the mixtures containing the PC, SF and LP while the PC replacements with the LP were 5, 10 and $20 \%$ by weight. The PC replacements with the total of SF and LP were 30, 35 and $45 \%$ by weight in the mixtures LP. The mixture proportions were given in Table 2.

\begin{tabular}{lccccccc} 
& W/B & W & PC & SF & LP & Sand & HRWR \\
Control & 0.46 & 294 & 640 & - & - & 1293 & 1.28 \\
\hline SF25 & 0.46 & 294 & 480 & 160 & - & 1224 & 8.32 \\
\hline SF25LP5 & 0.46 & 294 & 448 & 160 & 32 & 1218 & 8.32 \\
\hline SF25LP10 & 0.46 & 294 & 416 & 160 & 64 & 1212 & 8.32 \\
\hline SF25LP20 & 0.46 & 294 & 352 & 160 & 128 & 1200 & 8.32
\end{tabular}

Table 2. Mixture proportioning of used materials $\left(\mathrm{kg} / \mathrm{m}^{3}\right)$ 2. táblázat A felhasznált anyagok keverési aránya $\left(\mathrm{kg} / \mathrm{m}^{3}\right)$

The minimum PC amount was selected as $352 \mathrm{~kg} / \mathrm{m}^{3}$ to satisfy EN 206-1 [39] requirement which was $340 \mathrm{~kg} / \mathrm{m}^{3}$. The water/binder ratio (W/B) was selected as 0.46 . During the preparation of fresh mixtures, the powder materials and sand were mixed for $1 \mathrm{~min}$. as described in ASTM C109 [40]. Then, HRWRA and water was poured on these materials. The mixture was further mixed for $4 \mathrm{~min}$. Following EFNARC standard [2], the suitability of fresh mortar mixtures was tested by the mini-slump and V-funnel apparatus. The specifications of mini-slump and V-funnel flow apparatus were given in 
detail in EFNARC standard [2]. In the mini slump test, the frustum was placed on a flat surface and filled with mortar. Later, the frustum was lifted upwards. Thus, the diameter of the spread mortar was measured on perpendicular to one another. The average diameter was calculated from these two measurements. In the V-funnel flow test, the mortar was filled into the $\mathrm{V}$-funnel flow apparatus. The gate at the bottom of the apparatus was opened and the discharge time $(t)$ of the mortar was measured. The moulds were filled with fresh mixtures and they were demoulded after 24 hours. All samples were cured in water at $23{ }^{\circ} \mathrm{C}$ until testing. $\varphi 75 \times 150 \mathrm{~mm}$ cylinder samples were used to determine compressive strengths after 7, 28 and 90 days. The dry unit weight, water absorption and sorptivity tests were also performed on the $\varphi 75 \times 150 \mathrm{~mm}$ cylindrical samples at the age of 90 days.

The drying shrinkage tests on the mortar samples were performed in accordance with ASTM C596 [41]. This test method determined the change in length on the drying of mortar bar with dimensions of $25 \times 25 \times 285 \mathrm{~mm}$. The moist cure of samples was made in the moulds for $48 \mathrm{~h}$ at $23{ }^{\circ} \mathrm{C}$ in water. Then samples were removed from moulds and cured in the lime-saturated water for 24 hours. The samples were taken from the water at the age of 72 hours and their surfaces were wiped with damp cloth. The lengths of samples were measured by the comparator. Then the samples were placed in the air storage for 25 days. The length readings for each sample were performed at $4,11,18$, and 25 days of air storage. The length change of each sample at each age of air drying was determined by subtracting the initial length from the reading taken at each age of air drying.

The viscosity values were measured by Brookfield DV-E model viscometer having a smooth-walled concentric cylinder. At lower stress values, the slip in the wall occurred and this condition caused the low yield stress measurements. The slip was most pronounced at the low strain rates, which led to unusual low viscosity readings. The influence of slip decreased while the deformation rate increased. Therefore, the viscosity measurements were conducted at different rotational speeds. The mortar mixture was poured into the pot of the viscometer. The average viscosity values were measured by upwards and downwards of each rotational speed steps. The unit weight, water absorption and sorptivity tests were also performed on the $\varphi 75 \times 150 \mathrm{~mm}$ cylinder samples by following ASTM C642 [42] and BS EN 772-11 [43].

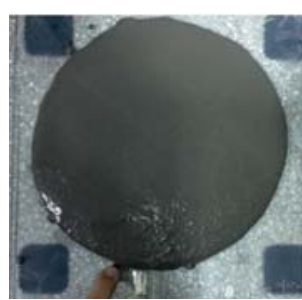

Control

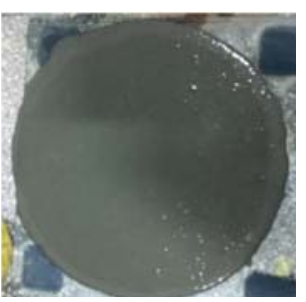

SF25

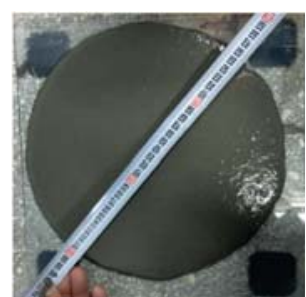

SF25LP5

\section{Results and discussions}

\subsection{Slump, flow, segregation and rheological properties}

All of the SCMs were produced to obtain a slump flow diameter of $25 \pm 1 \mathrm{~cm}$ by adjusting the dosage of HRWR admixture. As shown in Fig. 1a, the Control mixture made slight segregation between the sand and paste. In the SF mixture, there was an over segregation among the water, sand and paste. It was reported in earlier studies by different researchers that the segregation problem occurred in the SCMs or concretes when the PC replacement with the SF was higher than 15\% by weight. Therefore, the segregation of SF25 mixture was an expected event. The water bleeding occurred at the outermost of flow ring as shown in Fig. $1 b$ in the SF25 mixture. The slight segregation also occurred in the SF25LP5 mixture. When compared with the SF25 mixture, the segregation of SF25LP5 mixture was different than that of the SF25. The segregation occurred between the sand and paste in the SF25LP5 but there was also slight water bleeding on the outermost of flow ring as shown in Fig. 1c. As shown in Figs. $1 d$ and 1e, the SF25LP10 and SF25LP20 did not show any segregation and their surfaces were considerably smooth.

Li and Kwan [44] reported that the addition of LP into the concrete would increase the cohesiveness of mix to avoid segregation. Turgut et al. [45] showed in their newly developed segregation testing device that LP effectively prevented the segregation of SCC when compared with the SF and FA powders.

The apparent viscosity and RPM (Rotation per Minute) relationship of mixtures were shown in Fig. $2 a$. The viscosity of Control mixture was the lowest in all mixtures while those of the SF25 and SF25LP5 were higher. It could be said that the $5 \%$ LP did not decrease the viscosity of SF25LP5 mixture and did not effectively improve the rheological properties. The rheological properties of SF25LP10 and SF25LP20 mixtures were improved when the PC replacements with the LP were 10 and $20 \%$ in the SF25 mixture. The increase of LP amount decreased the viscosity value in the mixtures and this result was consistent with that of Vikan and Justnes [18]. Another important thing was that the HRWR amount stayed as constant although the water/binder powder ratio was the same in the SF25, SF25LP5, SF25LP10 and SF25LP20 mixtures. It was expected that the HRWR amount should have increased due to the increase of powder amounts in SF25LP5, SF25LP10 and SF25LP20 mixtures. This showed that the LP dispersed more effectively the PC and SF particles than the HRWR. Vikan and Justnes [18] also found that the LP dispersed the PC particles

Fig. 1. Slump flow and segregation of SCMs

1. ábra Az SCM tartalmú minták terülése és szétosztályozódása

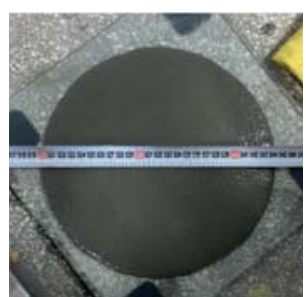

SF25LP10

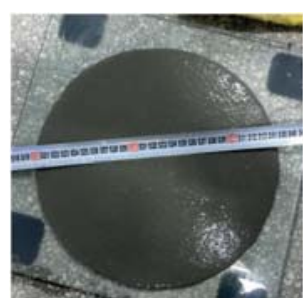

SF $25 L P 20$ 
more effectively than that of the SF in their work. As shown in Fig. 2b, the V-funnel flow time of mixtures with LP was decreased as compared with the SF25 mixture.

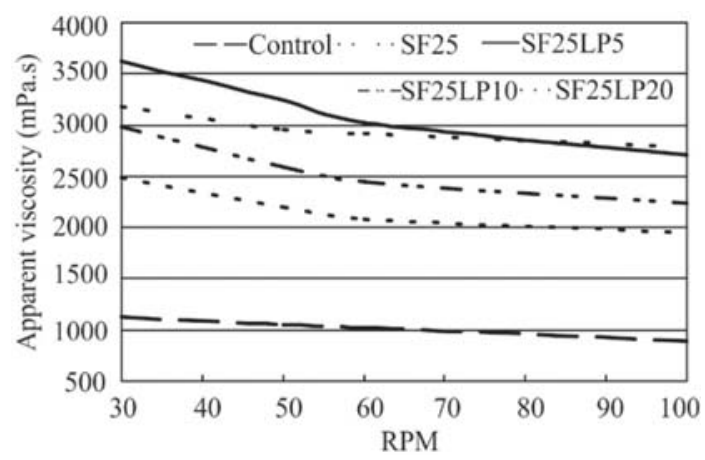

Apparent viscosity of mixtures

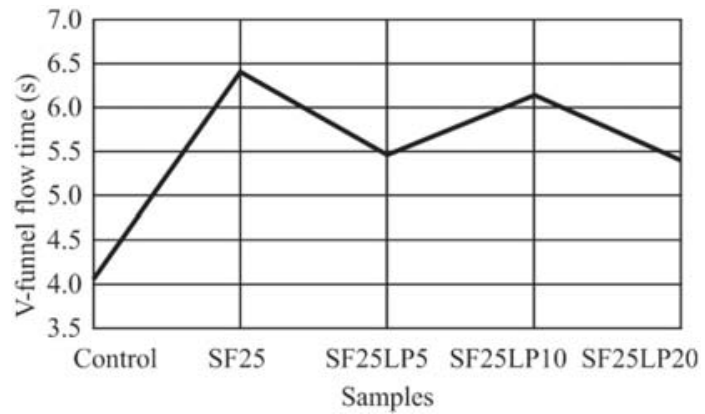

$V$-funnel flow time of mixtures

Fig. 2. Rheological properties of mixtures

2. ábra A keverékek reológiai tulajdonságai

\subsection{Compressive strength}

In Fig. $3 a$ and $b$, the compressive strengths of samples are shown at 7,28 and 90 days. At these time points, the compressive strength of Control sample was higher than those of the other samples containing the mineral admixtures. The decrease in the compressive strength at the 7 day was the proportional with the increase of LP amount. The compressive strengths of SF25 sample at the 28 and 90 days were lower than those of the Control sample at these time points. Moreover, the compressive strengths of SF25 sample were nearly identical at the 28 and 90 days although it was expected an increase in their values because of the pozzolanic effect of SF. It was pointed out earlier that the segregation occurred in the SF25. Why did the compressive strength decrease in the SF25 sample although the SF had an excellent pozzolanic property as mixed with the PC? Why did the compressive strengths increase again in the SF25LP5, SF25LP10 and SF25LP20 samples as compared with the SF25 sample? The analogy of decrease or increase in the compressive strength was shown in Fig. 4. As shown in Fig. 4, the PC and sand particles moved downward as the SF particles moved upwards because of segregation in the SF25 sample. The PC and sand amount were lower while the $\mathrm{W} / \mathrm{B}$ ratio and the SF amount were higher in region 1 above the dotted line as compared to region 2 below this line. Thus, region 1 above the dotted line was firstly fractured because of the low strength value. It could be said that the SF did not efficiently show the pozzolanic effect because of higher SF and lower PC amounts in region 1. Another reason of strength decrease was the higher $\mathrm{W} / \mathrm{B}$ ratio in this region. In the SF25 samples containing the LP, SF was uniformly distributed among the PC, LP and sand due to the effect of LP. As shown in Fig. $4 b$, the increase in the strength at the 90 day in these samples with LP might be due to the pozzolanic effect of SF. Chen and Kwan [46] argued that the LP particles might have acted as nuclei for precipitation of $\mathrm{CSH}$, which increased the degree of PC hydration. They also reported that the LP reduced the bleeding in the concrete mixtures and thus, improved the bond strength of interfacial transition zone between the aggregate and mortar surface. Another thing was that the compressive strength increased in the SF25LP5, SF25LP10 and SF25LP20 samples as compared to the SF25 sample although the PC amounts were decreased in the samples with LP. As given in Table 2, the PC amounts were $480,448,416$ and $352 \mathrm{~kg} / \mathrm{m}^{3}$ for the SF25, SF25LP5, SF25LP10 and SF25LP20 samples, respectively. The highest compressive strength increase at 90 days as compared to 28 days as percent was in SF25LP10 sample.
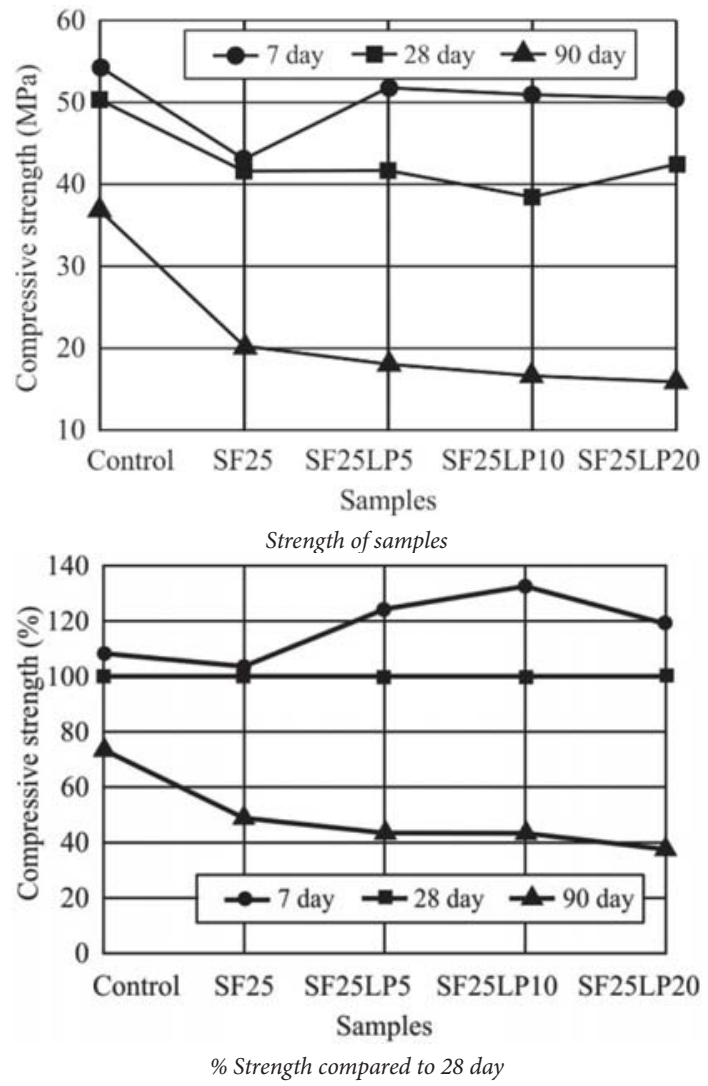

Fig. 3. Compressive strength variation of samples

3. ábra A vizsgált minták nyomószilárdságának változása időben

\subsection{Fresh-hardened unit weight and water absorption- sorptivity}

The fresh and hardened dry unit weight values of samples were shown in Fig. 5a. The fresh and hardened dry unit weight values of the Control sample were higher than those of the other samples with the SF and LP. This was the expected because the density of PC was higher than those of SF and LP. The unit weight values of SF sample was the lowest due to the increase of paste volume in the mixture. The interesting 


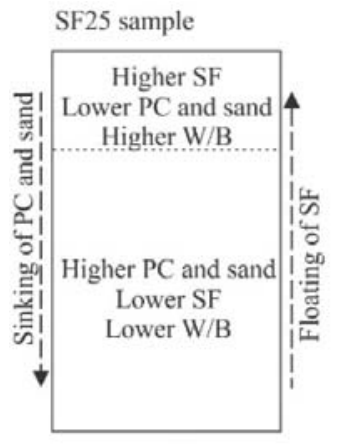

(1) Low strength region

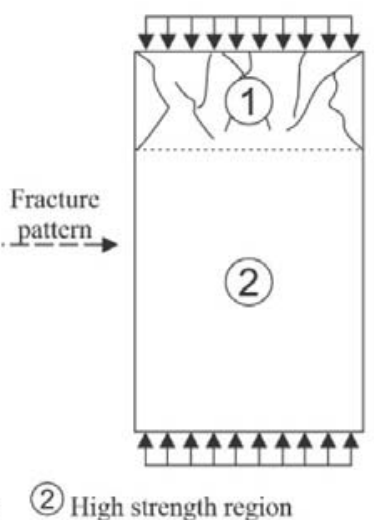

(2) High strength region

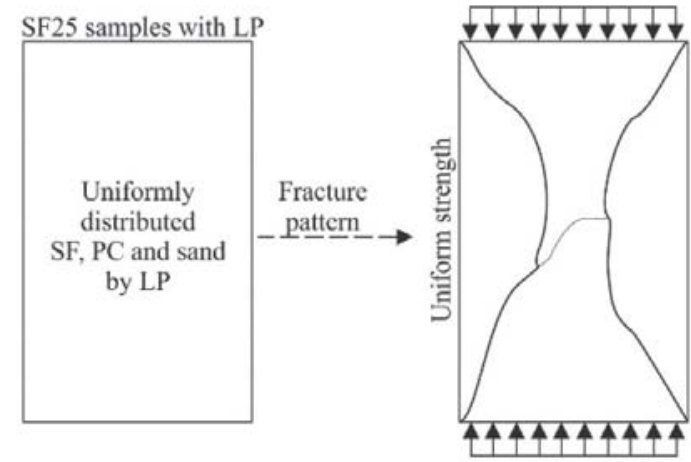

Fig. 4. Fracture pattern of SF25 and SF25 with LP samples

4. ábra Az SF25 valamint az LP tartalmú SF25 minták törésképe

situation occurred in the SF25LP5, SF25LP10 and SF25LP20 samples. It was expected that their unit weight values were lower than that of the SF25 sample due to the lower density of LP (2.54) as compared with the PC (3.1). The PC replacements with the total of SF and LP were 30, 35 and 45\% in the SF25LP5, SF25LP10 and SF25LP20 samples. Moreover, the PC amounts were effectively decreased in these samples. The unit weight values of SF25LP5, SF25LP10 and SF25LP20 samples were higher than that of the SF25 sample. This could be originated from the various grain sizes of the SF and LP causing a good packing. The LP particles filled the pores between the large PC particles and the density of paste increased [27-28,47].

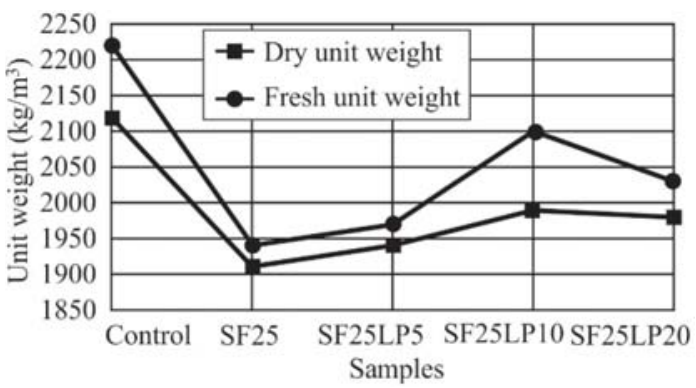

(a) Fresh and hardened dry unit weight

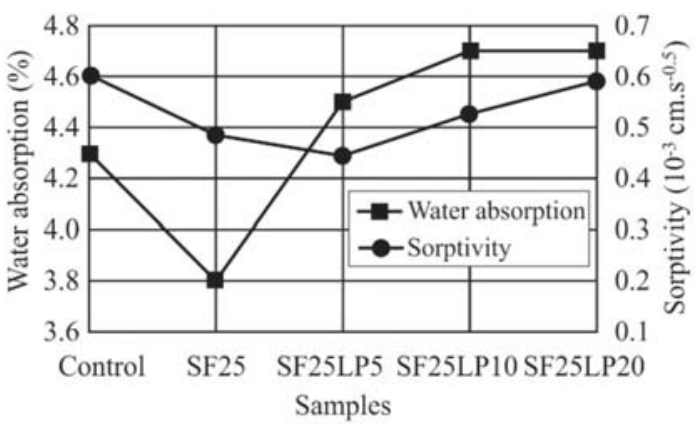

(b) Water absorption and sorptivity

Fig. 5. Fresh/hardened dry unit weights and water absorption/sorptivity of samples 5. ábra A minták friss / megszilárdult sürüsége valamint vízfelvétele / kapilláris vízfelvétele

The water absorption and sorptivity of samples were shown in Fig. 5b. The lowest water absorption was obtained from the SF25 sample while the water absorptions were the highest in the SF25LP10 and SF25LP20 samples. The increase in the water absorption of samples with the LP could be originated from the porous structure of LP. As shown in Fig. 5b, the sorptivity had an optimum value in the SF25LP5 sample. Then, the sorptivity increased due to the increase of LP in the SF25LP10 and SF25LP20 samples. The sorptivity of Control and SF25LP20 sample were nearly identical. A hardened paste structure with fine pores due to the LP could be occurred in the SCC [48]. Thus, the capillary forces increased due to the increase in the total area of pore surface in the hardened paste. The sorptivity values of high performance concretes produced by Bharatkumar et al. [49] varied between the $0.62 \times 10^{-3} \times \mathrm{cm} . \mathrm{s}^{-}$ 0.5 and $1.47 \times 10^{-3} \times \mathrm{cm}^{-0.5}$. Tasdemir [50] also performed the sorptivity tests in the concretes with the LP, SF, FA and stone powder and reported that the sorptivity values varied between $0.46 \times 10^{-3} \times \mathrm{cm} . \mathrm{s}^{-0.5}$ and $0.77 \times 10^{-3} \times \mathrm{cm} . \mathrm{s}^{-0.5}$. In this work, the sorptivity values varied between $0.60 \times 10^{-3} \times \mathrm{cm} . \mathrm{s}^{-0.5}$ and $0.45 \times 10^{-3} \times \mathrm{cm}^{-0.5}$ and were near the reference $[49,50]$.

\subsection{Drying shrinkage}

The drying shrinkage (DS) values at $4,11,18$ and $25^{\text {th }}$ days are shown in Fig 6. The DS values of all samples increased with time. The DS value of SF25LP10 was the lowest at $4^{\text {th }}$ day while that of the SF25 was the highest at $4^{\text {th }}$ and $25^{\text {th }}$ day. At $4^{\text {th }}$ day, the DS value of Control sample was lower than that of the SF25. It was interesting that the DS values of the Control and SF25LP10 samples were nearly identical at $4^{\text {th }}, 18^{\text {th }}$ and $25^{\text {th }}$ days. Setter and Roy [16] and Rao [17] found that the SF significantly increased the DS of concrete. They also reported that the SF did not increase the DS at later ages while increasing at early ages due to the starting of pozzolanic reaction effect of the SF. One of the reasons in the increase of the DS was the surface tension on the secondary CSH gels occurred with the reaction between the $\mathrm{CH}$ and SF. It was reported that the specific surface area of LP affected the DS of concrete [51-52]. The density of micro-structure of hardened paste increased when the specific surface area of LP was higher than that of the PC. Thus, the DS of mortar with the LP was decreased. As seen in Fig. 5a, the fresh and hardened unit weight values of SF25LP10 sample were higher than those of the other samples with the LP and SF. This showed that the DS of SF25LP10 sample was low due to its dense structure. Adam and Race [53] investigated several cements with the additions of grounded or blended LP. Their data indicated that the addition of 2 to $5 \%$ limestone in Type I or Type II cement could significantly 
increase DS at $4^{\text {th }}$ day. In this study, the DS values in the samples with the LP at $4^{\text {th }}$ day were lower than those of the Control and SF25 although the LP amount increased in the samples. Dhir et al. [54] reported that the general trend for the DS was a reduction with the increase of LP amount in the PC concrete. Barrett et al. [55] investigated the DS of PC containing up to the 15\% LP. They showed that the measured autogenous shrinkage in the PC and the PC containing LP systems were nearly equal.

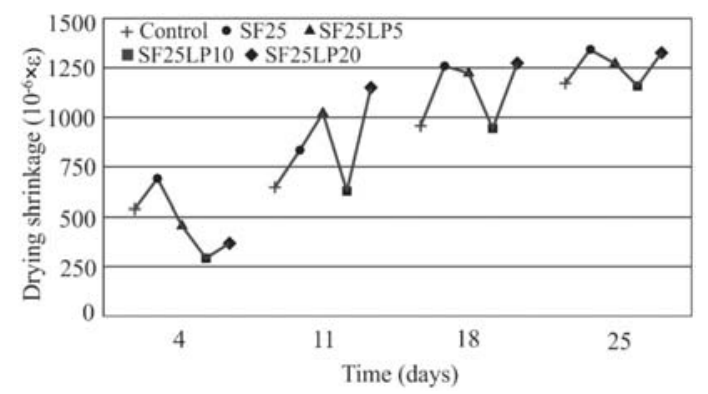

Fig. 6. Drying shrinkage

6. ábra A minták száradási zsugorodása

\section{Conclusion}

The paper dealt with optimum LP amount in SCM with 25\% $\mathrm{SF}$ to improve some properties of SCM. The optimum amount of LP was found $10 \%$ in SCM containing 25\% SF. $10 \%$ LP used in SCM increased the compressive strength by preventing segregation and decreased the drying shrinkage of SCM. Water absorption and sorptivity values of SCM increased in 10\% LP compared to SCM with $25 \%$ SF but they were acceptable levels. The rheological properties of mixtures were also improved at $10 \%$ LP amount.

\section{References}

[1] Hayakawa, M. - Matsuoka, Y. - Shindoh, T. (1994): Development and application of super -workable concrete. Proceedings of International RILEM workshop on the special concretes - workability and mixing, 1994, 2: 183-90.

[2] EFNARC, Specifications and guidelines for self-compacting concrete, English ed. European federation for specialist construction chemicals \&concrete systems, 2005.

[3] Khayat, K. - Hu, C. - Monty, H. (1999): Stability of self-consolidating concrete, advantages, and potential applications. Proceedings of International RILEM symposium on self compacting concrete, 1999, 1: 143-52.

[4] Ye, G. - Liu, X. - De Schutter G. - Poppe, A. M. - Taerwe, L. (2007): Influence of limestone powder used as filler in SCC on hydration and microstructure of cement pastes. Cement and Concrete Composites. Vol. 29, No. 2, pp. 94-2. https://doi.org/10.1016/j.cemconcomp.2006.09.003

[5] Oh, S. G. - Noguchi, T. - Tomosawa, F. (1999): Toward mix design for rheology of self-compacting concrete. Proceedings of International RILEM symposium on self compacting concrete, 1999, 1: 361-72.

[6] Skarendahl, Å. - Tangtermsirikul, S. - Kamal, K. - Petersson, Ö. (2000): Self-Compacting Concrete-State-of-the-Art Report of RILEM TC 174SCC. RILEM report, 23.

[7] Sari, M. - Prat, E. - Labastire, J. F. (1999): High strength self-compacting concrete original solutions associating organic and inorganic admixtures. Cement and Concrete Research. Vol. 29, No. 6, pp. 813-8. https://doi.org/10.1016/s0008-8846(99)00037-x

[8] Galetakis, M., - Soultana, A. (2016): A review on the utilisation of quarry and ornamental stone industry fine by-products in the construction sector. Construction and Building Materials. Vol. 102, pp. 769-81. https://doi.org/10.1016/j.conbuildmat. 2015.10.204
[9] Neville, A.M. (2011): Properties of Concrete, 5th edition, Longman, Pearson Education.

[10] Bayasi, Z - Zhou, J. (1993): Properties of silica fume concrete and mortar. ACI Materials Journal. Vol. 90, No. 4, pp. 349-6. https://doi.org/10.14359/3892

[11] Cheng-Yi, H - Feldman, R. F. (1985): Hydration reactions in Portland cement-silica fume blends. Cement and Concrete Research. Vol. 15, No. 4, pp. $585-2$. https://doi.org/10.1016/0008-8846(85)90056-0

[12] Feldman, R. F. - Cheng-Yi, H. (1985): Properties of Portland cement-silica fume pastes II. Mechanical properties. Cement and Concrete Research. Vol. 15, No. 6, pp. 943-2. https://doi.org/10.1016/0008-8846(85)90083-3

[13] Cohen, M. D. - Klitsikas, M. (1986): Mechanisms of hydration and strength developments in Portland cement composites containing silica fume particles. Northeastern University.

[14] Cohen, M. D. (1990): A look at silica fume and its actions in Portland cement concrete. Indian Concrete Journal. Vol. 64, No. 9, pp. 429-38.

[15] Rao, G. A. (2003): Investigations on the performance of silica fumeincorporated cement pastes and mortars. Cement and Concrete Research. Vol. 33, No. 11, pp. 1765-0. https://doi.org/10.1016/s0008-8846(03)00171-6

[16] Setter, N. - Roy, D. M. (1978): Mechanical features of chemical shrinkage of cement paste. Cement and Concrete Research. Vol. 8, No. 5, pp. 623-34. https://doi.org/10.1016/0008-8846(78)90045-5

[17] Rao, G. A. (1998): Influence of silica fume replacement of cement on expansion and drying shrinkage. Cement and Concrete Research. Vol. 28, No. 10, pp. 1505-09. https://doi.org/10.1016/s0008-8846(98)00127-6

[18] Vikan, H. - Justnes, H. (2007): Rheology of cementitious paste with silica fume or limestone. Cement and Concrete Research. Vol. 37, No. 11, pp. 1512-17. https://doi.org/10.1016/j.cemconres.2007.08.012

[19] Diamantonis, N. - Marinos, I. - Katsiotis, M. S. - Sakellariou, A. Papathanasiou, A. - Kaloidas, V. - Katsioti, M. (2010): Investigations about the influence of fine additives on the viscosity of cement paste for self-compacting concrete. Construction and Building Materials. Vol. 24, No. 8, pp. 1518-22. https://doi.org/10.1016/j.conbuildmat.2010.02.005

[20] Bosiljkov, V. B. (2003): SCC mixes with poorly graded aggregate and high volume of limestone filler. Cement and Concrete Research. Vol. 33, No. 9, pp. 1279-86. https://doi.org/10.1016/s0008-8846(03)00013-9

[21] Felekoglu, B. (2007): Utilisation of high volumes of limestone quarry wastes in concrete industry (self-compacting concrete case). Resources, Conservation and Recycling. Vol. 51, No. 4, pp. 770-91. https://doi.org/10.1016/j.resconrec.2006.12.004

[22] Pera, J. - Husson, S. - Guilhot, B. (1999): Influence of finely ground limestone on cement hydration. Cement and Concrete Composites. Vol. 21, No. 2, pp: 99-05. https://doi.org/10.1016/s0958-9465(98)00020-1

[23] Bonavetti, V. - Donza, H. - Rahhal, V. - Irassar, E. (2000): Influence of initial curing on the properties of concrete containing limestone blended cement. Cement and Concrete Research. Vol. 30, No. 5, pp. 703-8. https://doi.org/10.1016/s0008-8846(00)00217-9

[24] Nehdi, M. (2000): Why some carbonate fillers cause rapid increases of viscosity in dispersed cement-based materials. Cement and Concrete Research. Vol. 30, No. 10, 1663-69. https://doi.org/10.1016/s0008-8846(00)00353-7

[25] Nehdi, M. - Mindess, S. - Aitcin, P. C. (1998): Rheology of highperformance concrete: effect of ultrafine particles. Cement and Concrete Research. Vol. 28, No. 5, pp. 687-97. https://doi.org/10.1016/s0008-8846(98)00022-2

[26] Ghezal, A. - Khayat, K. H. (2002): Optimizing self-consolidating concrete with limestone filler by using statistical factorial design methods. ACI Materials Journal. Vol. 99, No. 3, pp. 264-72. https://doi.org/10.14359/11972

[27] Tragardh, J. (1999): Microstructural features and related properties of selfcompacting concrete. Proceedings of International RILEM symposium on self compacting concrete, 1999, 1: 175-86. 
[28] Billberg, P. (1999): Fine mortar rheology in mix design of SCC. Proceedings of International RILEM symposium on self compacting concrete, 1999, 1: 47-58.

[29] Belarbi, N. - Pons, G. - Perrin, B. (1997): Delayed behaviour of concrete: influence of additions and aggregate characteristics in relation to moisture variations. Cement and Concrete Research. Vol. 27, No. 9, pp. 1429-38. https://doi.org/10.1016/s0008-8846(97)00125-7

[30] Petersson, O. (2001): Limestone powder as filler in self-compacting concrete-frost resistance and compressive strength. Proceedings of International RILEM symposium on self compacting concrete, 2001, 2: 277-84.

[31] Turkel, S. - Altuntas, Y. (2009): The effect of limestone powder, fly ash and silica fume on the properties of self-compacting repair mortars. Sadhana. Vol. 34, No. 2, 331-43. https://doi.org/10.1007/s12046-009-0011-3

[32] Bombled, J. P. (1986): Rhéologie du béton frais: Influence de lájout de fillers aux ciments. Proceedings of 8th International Congress on the Chemistry of Cement, 1986, 4: 190-96.

[33] Escadeillas, G. (1988): Les ciments aux fillers calcaires: Contribution a leur optimisation par létude des propriétés mécaniques et physiques des bétons fillérisés. Doctoral dissertation, Thèse de Doctorat de l'Université Paul SABATIER, Toulouse.

[34] Neto, C. S. - Campiteli, V. C. (1990): The influence of limestone additions on the rheological properties and water retention value of Portland cement slurries. In Carbonate additions to cement. ASTM International.

[35] Brookbanks, P. (1989): Properties of fresh concrete, performance of limestone filled cements. Proceedings BRE/BCA seminar, Garston. 1989: 4.

[36] Nehdi, M. - Mindess, S. - Aitcin, P. C. (1997): Statistical modelling of the micro filler effect on the rheology of composite cement pastes. Advances in Cement Research. Vol. 9, No. 33, pp. 37-46. https://doi.org/10.1680/adcr.1997.9.33.37

[37] Kounakoff, B. A. - Hanzic, L., - Ho, J. C. M. (2017): Limestone and silica fume to improve concurrent flowability-segregation limits of concrete. Magazine of Concrete Research. Vol. 69, No. 23, pp. 1189-02. https://doi.org/10.1680/jmacr.16.00387

[38] ASTM C33 (2018): Standard specification for concrete aggregates. https://doi.org/10.1520/C0033_C0033M-18

[39] BS EN 206-1 (2013): Concrete: Specification, performance, production and conformity. https://doi.org/10.3403/30257890

[40] ASTM C109 (2016): Standard test method for compressive strength of hydraulic cement mortars (using 2 -in. or [50-mm] cube specimens) https://doi.org/10.1520/C0109_C0109M-16A

[41] ASTM C596 (2018): Standard test method for drying shrinkage of mortar containing hydraulic cement. https://doi.org/10.1520/C0596-18

[42] ASTM C642 (2013): Standard test method for density, absorption, and voids in hardened concrete. https://doi.org/10.1520/C0642-13

[43] BS EN 772-11 (2011): Methods of test for masonry units. Determination of water absorption of aggregate concrete, autoclaved aerated concrete, manufactured stone and natural stone masonry units due to capillary action and the initial rate of water absorption of clay masonry units. https://doi.org/10.3403/30215381
[44] Li, L. G. - Kwan, A. K. (2015): Adding limestone fines as cementitious paste replacement to improve tensile strength, stiffness and durability of concrete. Cement and Concrete Composites. Vol. 60, 17-24. https://doi.org/10.1016/j.cemconcomp.2015.02.006

[45] Turgut, P. - Turk, K. - Bakirci, H. (2012): Segregation control of SCC with a modified L-box apparatus. Magazine of Concrete Research. Vol. 64, No. 8, pp. 707-16. https://doi.org/10.1680/macr.11.00144

[46] Chen J. J. - Kwan A. K. H. (2012): Adding limestone fines to reduce heat generation of curing concrete. Magazine of Concrete Research. Vol. 64, No. 12, pp. 1101-11.

https://doi.org/10.1680/macr.11.00193

[47] Barnes, H. A. - Hutton, J. F. - Walters, K. (1989): An introduction to rheology. Elsevier. https://doi.org/10.1016/b978-0-444-87469-6.50005-6

[48] Valcuende, M. - Marco, E. - Parra, C. - Serna, P. (2012): Influence of limestone filler and viscosity-modifying admixture on the shrinkage of self-compacting concrete. Cement and Concrete Research. Vol. 42, No. 4, pp. 583-92. https://doi.org/10.1016/j.cemconres.2012.01.001

[49] Bharatkumar, B. H. - Narayanan, R. - Raghuprasad, B. K. Ramachandramurthy, D. S. (2001): Mix proportioning of high performance concrete. Cement and Concrete Composites. Vol. 23, No. 1, pp. 71-80. https://doi.org/10.14359/9807

[50] Tasdemir, C. (2003): Combined effects of mineral admixtures and curing conditions on the sorptivity coefficient of concrete. Cement and Concrete Research. Vol. 33, No.10, pp.1637-42.

https://doi.org/10.1016/s0008-8846(03)00112-1

[51] Van Khanh, B. - Montgomery, D. (1999): Drying shrinkage of selfcompacting concrete containing milled limestone. Proceedings of International RILEM symposium on self compacting concrete, 1999, 1:227-38.

[52] Klug, Y. - Holschemacher, K. (2003): Comparison of the hardened properties of self-compacting and normal vibrated concrete. Proceedings of International RILEM symposium on self compacting concrete, 2003, 3: 596-05.

[53] Adams, L. D. - Race, R. M. (1990): Effect of limestone additions upon drying shrinkage of Portland cement mortar. In Carbonate additions to cement. ASTM International.

[54] Dhir, R. K. - Limbachiya, M. C. - McCarthy, M. J. - Chaipanich, A. (2007): Evaluation of Portland limestone cements for use in concrete construction. Materials and Structures. Vol. 40, No. 5, pp. 459-73.

[55] Barrett, T. - Sun, H. - Villani, C. - Barcelo, L. - Weiss, J. (2014): Early-age shrinkage behaviour of Portland limestone cement. Concrete International. Vol. 36, No. 2, pp. 51-7.

Ref.:

Turgut, Paki - Ogretmen, Abdullah: Optimum limestone powder amount in mortars with over silica fume Építőanyag - Journal of Silicate Based and Composite Materials, Vol. 71, No. 2 (2019), 58-64. p. https://doi.org/10.14382/epitoanyag-jsbcm.2019.11

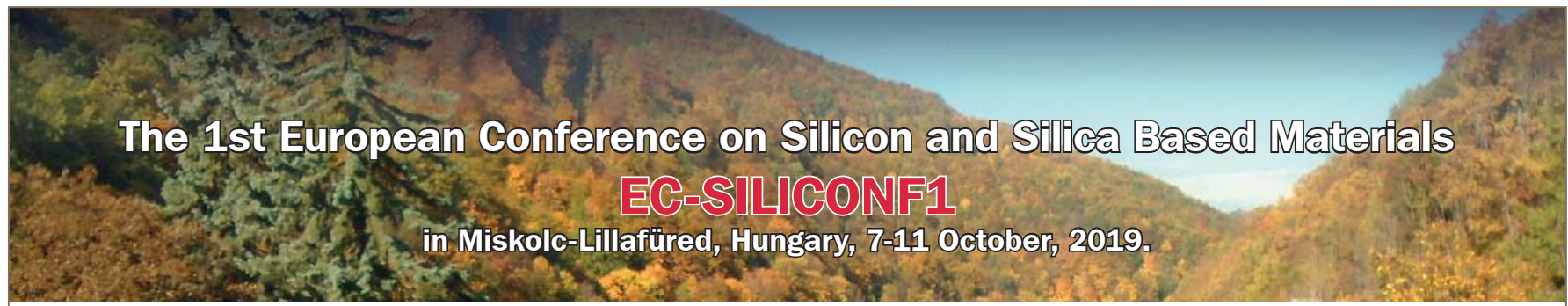

The aims of the ec-siliconf1 are the creation of an interdisciplinary European and worldwide forum on the silicon and silica content materials and fostering of collaboration among scientists, researchers, PhD students, engineers as well as universities, research institutions and industry.

We hope to see and welcome you in Hungary in the Beech Mountains at Miskolc-Lillafüred in October 7-11 ${ }^{\text {th }}, 2019$.

\section{www.ec-siliconf.eu}

Further information can be obtained from conference secretariat by email: euro.siliconf@gmail.com 